\title{
PENGARUH PEMBERIAN AIR REBUSAN BUAH MAHKOTA DEWA TERHADAP KADAR ASAM URAT DARAH PADA WANITA MENOPAUSE DI WILAYAH KERJA PUSKESMAS TILANGO KABUPATEN GORONTALO
}

\author{
Ni Nengah Mustiari' ${ }^{1}$, Nancy Olii ${ }^{2}$, Endah Yulianingsih ${ }^{3}$ \\ 1,2,3 Jurusan Kebidanan Poltekkes Kemenkes Gorontalo
}

Abstrak

Peningkatan kadar asam urat dalam darah atau hiperuricemia juga merupakan salah satu prediktor kuat terhadap kematiaan karena kerusakan kardiovaskuler. Tujuan dari penelitian ini untuk mengetahui pengaruh rebusan buah mahkota dewa terhadap penurunan kadar asam urat pada wanita menopause di Puskesmas Tilango Kabupaten Gorontalo 2018. Peneliti ini termasuk jenis pra eksperimental dengan menggunakan One Group Pretest-Posttest Design, dimana peneliti akan menganalisis pengaruh rebudan buah mahkota dewa terhadap penurunan kadar asam urat darah pada wanita menopause di Puskesmas Tilango Kabupaten Gorontalo Tahun 2018. Dalam penelitiaan ini populasi berjumlah 30 orang,dan sampel dalam penelitian ini adalah Purposive sampling. Hasil penelitian yang didapatkan bahwa distribusi responden berdasarkan kadar asam urat sebelum pemberian buah mahkota dewa di Puskesmas Tilango Kabupaten Gorontalo tahun 2018 yakni asam urat dengan kategori berlebihan sebanyak 30 orang (100\%), berdasarkan kadar asam urat sesudah pemberian buah mahkota dewa yakni kadar asam urat dengan kategori normal sebanyak 27 orang ( 90 $\%$ ) dan kadar asam urat kategori berlebih 3 orang (10\%), hasil Mc Nemar testdidapatkan nilai $p$ value $=0,000$ berarti $p$ value $<0,05$. Kesimpulan penelitian:Ada pengaruh air rebusan buah mahkota dewa terhadap penurunan kadar asam urat pada wanita menopause di Puskesmas Tilango Kabupaten Gorontalo.

Kata Kunci: Buah Mahkota Dewa; Asam Urat ; Menopause.

\section{THE EFFECT OF GIVING MAHKOTA DEWA FRUIT BOILED WATER ON BLOOD ACID LEVELS IN MENOPAUSE WOMEN IN THE WORKING AREA OF PUSKESMAS TILANGO GORONTALO}

\section{Abstract}

Increased uric acid levels in the blood or hyperuricemia are also strong predictors of death due to cardiovascular damage. The purpose of this study was to determine the effect of boiling the crown of the gods on reducing uric acid levels in menopausal women at Tilango Health Center, Gorontalo District 2018. This researcher is a pre-experimental type using One Group Pretest-Posttest Design, where the researcher will analyze the effect of the crown of the gods on reducing blood uric acid 
levels in menopausal women at Tilango Health Center, Gorontalo District in 2018. In this research, the population was 30 people, and The sample in this study is purposive sampling.

The results showed that the distribution of respondents based on uric acid levels before giving the god's crown fruit at Tilango Health Center, Gorontalo District in 2018, namely uric acid with an excessive category of 30 people (100\%), based on uric acid levels after giving the god's crown fruit, namely uric acid levels with the normal category of 27 people $(90 \%)$ and 3 people with excess uric acid levels (10\%), the Mc Nemar test results showed $\mathrm{p}$ value $=0,000$ meaning $\mathrm{p}$ value $<0.05$. Conclusion: There was an effect of boiled water from the crown of the gods on reducing uric acid levels in menopausal women at Tilango Health Center, Gorontalo.

Keywords: Anxiety; Health Education ; Video ; Primigravida

\section{Pendahuluan}

Di Indonesia, asam urat terjadi pada usia yang lebih muda, pada wanita kadar asam urat umumnya rendah dan meningkat setelah usia menopause. Prevalensi asam urat di Jawa Tengah, prevalensi pada kelompok usia 15-45 tahun sebesar 0,8\%; meliputi wanita 0,05\%. Di Minahasa (2003), proporsi kejadian asam urat sebesar 29,2\% dan pada etnik tertentu di Ujung Pandang sekitar 50\% penderita rata-rata telah menderita gout 65 tahun atau lebih setelah keadaan menjadi lebih parah. ${ }^{7}$

Berdasarkan data Biro Pusat Statistik (BPS) untuk proyeksi penduduk 2010, di Indonesia diperkirakan ada 5.846 .000 perempuan yang memasuki masa menopause yaitu 2,5\% dari penduduk Indonesia. Pada wanita menopause rentan terhadap berbagai penyakit. Salah satu akibat dari penurunan estrogen pada menopause adalah maningkatnya penumpukan asam urat dalam tubuh. asam urat merupakan sebutan orang awam untuk rematik pirai (gout artritis). Selain osteoartritis, asam urat merupakan jenis rematik artikuler terbanyak yang menyerang penduduk di Indonesia. Penyakit ini merupakan gangguan metabolik karena asam urat (uric acid) menumpuk dalam jaringan tubuh. ${ }^{5}$

Hasil survei WHO-ILAR Copcord (World Health Organization-International League of Associations for Rheumatology Community Oriented Program for Control of Rheumatic Disease) dipedesaan Sulawesi Utara dan Manado menemukan hubungan asam urat menahun dengan pola konsumsi dangaya hidup, diantaranya konsumsi alkohol dan kebiasaan makan makanan kaya purin. Selain itu, kebiasaan minum obat jenis diuretika (hidroklorotiazide), yaitu obat untuk menurunkan tekanan darah tinggi dapat meningkatkan kadar asam urat serum. ${ }^{12}$

Asam urat atau dikenal juga dengan istilah Gout Sementra penyakit asam urat tinggi disebut dengan istilah Aritritis Gout.ArtritisGout muncul sebagai serangan keradangan sendi yang timbul berulang - ulang Asam urat merupakan hasil metabolisme tubuh atau tepatnya hasil akhir dari kotabolisme suatu zat yang bernama purin. Zat purin merupakan salah satu ungsur protein yang ada dalam struktur rantai DNA dan RNA.Jadi asam urat adalah hasil buangan zat purin yang ikut mengalir bersama darah dalam pembulu darah. ${ }^{14}$

Dampak kadar asam urat dalam darah ditentukan oleh keseimbangan antara produksi (10\% pasien) dan Ekskresi (90\% pasien). Bila keseimbangan ini terganggu maka dapat 
menyebabkan terjadinya peningkatan kadar asam urat dalam darah yang disebut hiperurisemia. Hiperurisemia adalah keadaan dimana terjadi peningkatan kadar asam urat serum di atas normal. Pada sebagian besar penelitian epidemiologi, disebut sebagai hiperurisemia jika kadar asam urat serum orang dewasa lebih dari 7,0 mg/dl dan lebih dari $6,0 \mathrm{mg} / \mathrm{dl}$ pada perempuan. Secara klinis, hiperurisemia mempunyai arti penting karena dapat menyebabkan artritis gout, nefropati, dan nefrolithiasis. Masalah akan timbul jika terbentuk kristal-kristal monosodium urat monohidrat pada sendi-sendi dan jaringan sekitarnya. ${ }^{13}$

Daging buah mahkota dewa mengandung flavonoid. Ekstrak etanol 70\% daging buah mahkota dewa mempunyai kadar relatif flavonoid yang paling besar $(45,734 \mu \mathrm{g} / \mathrm{mg})$. Keefektifan mahkota dewa untuk mengobati asam urat diduga didasarkan pada kandungan flavonoidnya. Kemampuan senyawa tersebut dalam menurunkan asam urat adalah dengan mekanisme hambatan terhadap aktivitas xantin oksidase pada basa purin sehingga akan menurunkan produksi asam urat. Selain itu, tanaman tersebut juga digunakan untuk mengobati berbagai penyakit yakni lever, kanker dan tekanan darah tinggi. ${ }^{5}$

Berdasarkan data Stastistik yang ada di Gorontalo jumlah data menopause yang didapat pada tahun tahun 2016 yang ada di wilayah Gorontalo 263,8\% jiwa, Bualemo $39,26 \%$ jiwa, Pohuwato 0,09 \% jiwa, Bone Bolango 129.6\% jiwa, Gorontalo Utara 0,12\% jiwa, Kota Gorontalo 56,4\% jiwa, Provinsi Gorontalo $17.45 \%$ jiwa.

Dari data yang didapat di wilayah kerja Puskesmas Tilango Kabupaten Gorontalo, jumlah menopaus berjumlah 229 jiwa, dan 30 menopaus yang menderita asam urat. Dari Hasil wawancara dengan beberapa warga, mereka belum mengetahui bahwa rebusan buah mahkota dewa dapat menurunkan kadar asam urat dalam darah sehinga mereka perlu penjelasan tentang pentingnya buah mahkota dewa untuk mengobati dan menurunkan kadar asam urat pada wanita menopaus.

Berdasarkan penelitian sebelumnaya yang dilakukan oleh (Ika dan Dewi 2017) dapat dilihat bahwa rata-rata asam urat sesudah 7 hari diberikan intervensi adalah $7,5 \mathrm{ug} / \mathrm{mg}$ dan setelah 7 Hari diberikan intervensi yaitu 6,2ug/mg. hal ini menunjukkan ada perubahan pada kadar asam urat. Asam urat adalah asam yang berbentuk kristal-kristal yang merupakan hasil akhir dari metabolisme purin, yaitu salah satu komponen asam nukleat yang terdapat pada inti sel-sel tubuh dan secara alamaiah terdapat dalam tubuh. ${ }^{5}$

Penggunaan obat tradisional atau jamu di Indonesia terus meningkat, ditandai dengan bertambah banyaknya industri jamu/farmasi yang memproduksi obat tradisional/jamu.Dilain pihak penggunaan obat tradisional atau jamu dimasyarakat masih banyak yang bersifat empirik sehingga menimbulkan keraguan tentang mutu, khasiat dan keamanannya. ${ }^{11}$

Mahkota dewa (Phaleria macrocarpa) merupakan tanaman obat berasal dari Papua. Di Jawa Barat, tanaman ini disebut buah simalakama, di Jawa disebut Makutodewo. Seluruh bagian tanaman ini dikatakan dapat digunakan antara lain untuk kanker, lever, diabetes, asam urat, ginjal, penurun kolesterol dll ( Rohyami, 2008). Mahkota dewa (Pahaleria macrocarpa). Termasuk famili Thymelaceae merupakan salah satu tanaman asli idonesia yang ahir ini populer sebagai tanaman yang secara empiris dapat mengobati berbagai macam penyakit tanaman ini memiliki batang utama yang bercabang-cabang setinggi 1,5-2,5 m, daunnya 
tunggal berbentuk lonjong, dan berunjung lancip. Buahnya bulat dan berwarna merah tua jika matang, tanaman ini berasal dari irian dan tumbuh subur pada ketinggian 10-1.200 m. ${ }^{1}$

Salah satu tanaman obat yang dalam beberapa tahun belakangan ini banyak menarik perhatian masyarakat adalah mahkota dewa (Phaleria macrocarpa). Secara empirik, sebagian masyarakat menggunakan mahkota dewa untuk berbagai pengobatan tradisional antara lain untuk penyakit "asam urat" dan rematik, sakit ginjal maupun untuk penyakit ringan (seperti eksim, jerawat). Mahkota dewa bisa digunakan sebagai obat, dengan cara dimakan atau diminum, dan sebagai obat luar dengan cara dioleskan atau dilulurkan, dalam pengobatan bagian tanaman yang diperlukan adalah batang, daun, dan buah. ${ }^{3}$

Berdasarkan masalah yang sudah diuraikan di atas, maka penting untuk dilakukan penelitian tentang "Efektivitas Pemberian Air Rebusan Mahkota Dewa terhadap Kadar Asam Urat Darah pada Wanita Menopause 45-55 tahun di Wilayah Kerja Puskesmas Tilango Kabupaten Gorontalo.

\section{Metode}

Jenis penelitian ini kuantitatif dengan rancangan Pre Eksperimen dengan menggunakan One Group Prettest-Posttest Design. Penelitian dilaksanakan diPuskesmas Tilango Kabupaten Gorontalo pada tanggal 23 April sampai dengan 30 Apri 2018. Penelitian ini menggunakan dua variabel yaitu variabel bebas yaitu air rebusan buah mahkota dewa dan variabel terikat yaitu kadar asam urat darah pada menopause. Sedangkan populasi dalam penelitian ini adalah seluruh ibu menopause berjumlah 229 orang. Sampel yang digunakan dalam penelitian ini yaitu seluruh wanita menopause yang sesuai dengan kriteria inklusi dan eksklusi berjumlah 30 orang. Alat dan bahan yang digunakan untuk melakukan pemeriksaan kadar asam urat yaitu ET-GCU.

\section{Hasil dan Pembahasan}

Hasil penelitian dianalisis dengan menggunakan uji mc nemaart test untuk melihat pengaruh pemberian air rebusan buah mahkota dewa untuk menurunkan kadar asam urat darah pada wanita menopause. Dapat dilihat pada tabel berikut :

Tabel 1. Distribusi Responden Berdasarkan Umur Wanita Menopaus di Puskesmas Tilango Kabupaten Gorontalo

\begin{tabular}{ccc}
\hline Umur (tahun) & Jumlah & Persentase \\
\hline $45-50$ & 3 & 10,0 \\
$51-55$ & 27 & 90,0 \\
\hline Jumlah & 30 & 100,0 \\
\hline
\end{tabular}

Berdasarkan tabel di atas dapat diketahui bahwa usia menopause sebagian besar (90\%) dengan usia 51- 55 tahun. 
Tabel 2. Distribusi Responden Berdasarkan Pekerjaan Wanita Menopaus di Puskesmas Tilango Kabupaten Gorontalo

\begin{tabular}{ccc}
\hline Pekerjaan & Jumlah & Persentase \\
\hline IRT & 28 & 93,3 \\
PNS & 2 & 6,7 \\
\hline Jumlah & 30 & 100,0 \\
\hline
\end{tabular}

Berdasarkan tabel di atas dapat diketahui bahwa berdasarkan pekerjaan IRT (93,3\%).

Tabel 3. Pengaruh air rebusan buah mahkota dewa terhadap penurunan kadar asam urat darah pada wanita menopauase di Wilayah Kerja Puskesmas Tilango Kabupaten Gorontalo.

\begin{tabular}{lcc}
\hline Kadar asam urat setelah & Jumlah & Persentase \\
\hline Menurun & 27 & 90,0 \\
Tidak menurun & 3 & 10,0 \\
\hline \multicolumn{1}{c}{ Jumlah } & 30 & 100,0 \\
\hline
\end{tabular}

Berdasrkan tabel di atas hasil penelitiann yang didapatkan bahwa distribusi responden berdasarkan kadar asam urat sesudah pemberian buah mahkota dewa di Puskesmas Tilango Kabupaten Gorontalo Tahun 2018 yakni kadar asam urat dengan kategori berlebihan sebanyak $(10.0 \%)$.

Tabel 4. Pengaruh Pemberiaan Rebusan Buah Mahkota Dewa Terhadap Penurunan Kadar Asam Urat Darah Pada Wanita Menopause di Puskesmas Tilango Kabopaten Gorontalo.

\begin{tabular}{cccc}
\hline & Sebelum & Sesudah & \\
\cline { 2 - 3 } & Mean $\pm \mathrm{SD}$ & Mean \pm SD & P.Value \\
\hline Asam urat & $2.00 \pm .000$ & $1.10 \pm .305$ & 0.000 \\
\hline \multicolumn{2}{c}{ Hasil uji } & Mc Nemar Test di dapat kan nilai $\mathrm{p}$ value $=0,000$ berarti pvalue $<0,05$,
\end{tabular}
yang berarti ada pengaruh rebusan buah mahkota dewa terhadap penurunan kadar asam urat darah pada wanita menopause di puskesmas tilango kabupaten gorontalo tahun 2018.

Setelah pemberian air rebusan buah mahkota dewa responden mengalami peningkatan yaitu sebanyak 27 responden $(90 \%)$ dengan rata-rata kadar kadar asam urat responden sebelum perlakuan 14,2 dan rata-rata kadar asam urat responden sesudah perlakuan turun menjadi 12,8 dengan selisih rata-rata penurunan sebelum dan sesudah perlakuan yaitu 1,53 .

Kadar asam urat sebelum pemberiaan air rebusan buah mahkota dewa Hasil peneliti yang didapatkan bahwa distribusi responden berdasarkan kadar asam urat sebelum pemberiaan rebusan air rebusan buah mahkota dewa. Di Puskesmas Tilango Kabupaten Gorontaloto 2018 kadar asam urat dengan kategori berlebihan sebanyak 30 orang (100\%). Dari hasil penelitiaan tersebut bahwa kadar asam urat sebelum pemberiaan buah mahkota dewa adalah kelebihan semuaanya tidak dalam batas normal.

Menurut asumsi peneliti masih tingginya kadar asam urat dengan kategori berlebihan pada wanita menopaus Di Puskesmas Tilango Kabupaten Gorontalo disebabkan 
kadar asam urat pada wanita umumnya rendah dan baru meningkat setelah menopause. Responden wanita yang mengalami peningkatan kadar asam urat rata-rata berusia diatas 50 tahun dan terjadi pada masa menopause.

Asam urat terjadi terutama pada laki-laki, mulai dari usia pubertas hingga mencapai puncak usia 40-50 tahun, sedangkan pada perempuan, presentase asam urat mulai didapat setelah memasuki masa menopous. Kejadian asam urat baik di negara maju ataupun negara berkembang semakin meningkat terutama pada pria usia 40-50 tahun. Kadar asam urat pada pria meningkat sejalan dengan peningkatan usia seseorang. Hal ini terjadi karena pria tidak memiliki hormon estrogen yang dapat membantu membuang asam urat sedagkan perempuan memiliki hormon estrogen yang ikut membantu membuang asam urat lewat urin. ${ }^{17}$

Hasil penelitian ini di temukan bahwa kadar asam urat sesudah pemberiaan air rebusan buah mahkota dewa hasil penelitian yang didapatkan bahwa distribusi responden berdasarkan asam urat sesudah pemberiaan rebusan buah mahkota dewa di puskesmas tilango kabupaten gorontalo tahun 2018 yakni kadar asam urat dengan kategori normal sebanyak 27 orang $(90 \%)$ dan kadar asam urat dengan kategori berlebihan 3 orang $(10 \%)$.

Dalam penelitian ini mayoritas pada saat sebelum dilakukan pemberia rebusan buah mahkota dewa responden sering merasakan kaku-kaku pada sendinya dan kadar asam urat $>7 \mathrm{mg} / \mathrm{dl}$. Namaun setelah di berikan rebusan buah mahkota dewa dan diperiksa menggunakan GCU kadar asam urat menurun menjadi $<7 \mathrm{mg} / \mathrm{dl}$ (normal) sebanyak 27 orang dan $>7 \mathrm{mg} / \mathrm{dl}$ sebanyak 3 orang.

Kasiat yang terkandung dalam buah mahkota dewa mempunyai beberapa senyawasenyawa seperti saponin, falavonoid, dan akanoid yang banyak terdapat dalam buah mahkota dewanya. Kandungan dalam buah mahkota dewa yang dapat menurunkan kadar asam urat dengan menghambat berbagai reaksi oksidase, serta mampu bertindak sebagai produksi radikal hidroksil, superoksida dan radikal proksil. ${ }^{1}$

Hasil penelitian sejalan dengan penelitiaan sebelumnya yang dilakukan oleh (Ika, dan Erni , 2017) pengaruh rebusan buah mahkota dewa terhadap kadar asam urat darah pada wanita menopause di RW 01 Kelurahan Kebonsari Kecamatan Sukun Kota Malang didapatkan hasil rata - rata Penurunan kadar asam urat maupun selisih antara pre test yakni sekitar 1,53 mg/dl. Dibandingkan dengan kelompok kontrol yang tidak diberikan rebusan buah mahkota dewa terhadap penurunan kadar asam urat pada wanita menopause di Puskesmas Tilango Kabupaten Gorontalo tahun 2018. Hasil uji mc nemar test di dapat nilai $\mathrm{p}$ value $=0,000$.

Berdasarkan data yang diperoleh peneliti pada wanita menopause penyebab tingginya kadar asam urat responden yaitu aikibat dari konsumsi makanan yang mengandung tinggi purin seperti kacang tanah, bayam, buncis, daun singkong daging, dan kangkung.

Asam urat merupakan hasil metabolisme di dalam tubuh yang kadarnya tidak boleh berlebih, setiap orang memiliki asam urat di dalam tubuhnya, karena metabolisme normal akan dihasilkan asam urat sedangkan pemicunya adalah faktor makanan dan senyawa lain yang mengandung purin. ${ }^{12}$ 


\section{Kesimpulan}

1. Ada pengaruh air rebusan buah mahkota dewa terhadap penurunan kadar asam urat darah pada wanita menopause di wilayah kerja Puskesmas Tilango Kabupaten Gorontalo.

2. Ada pengaruh yang sangat signifikan pemberian rebusan air buah mahkota dewa terhadap kadar asam urat darah pada wanita Menopause di wilayah kerja Puskesmas Tilango Kabupaten Gorontalo $(\mathrm{p}=0,000)<(\alpha=0,05)$.

\section{Daftar Pustaka}

1. Ageon, 2010, Tanaman Obat Indonesia, Edwin tanujawa, Jakarta.

2. Destralanto, 2016, Desain Sistem Pakar Identifikasi Gejala Menopause, Jember, jurnal teknologi informasi dan terapan, Vol. 2 No. 2.

3. Handayani, 2016, Perbandingan Kadar Flavonoid Ekstrak Buah Mahkota Dewa (Phaleria macrocarpa [Scheff] Boerl) Secara Remaserasi Dan Perkolasi, Akademi Farmasi ISFI Banjarmasin, Jurnal Ilmiah Ibnu Sina. Vol. 1 No. 1.

4. Haroh , 2017, Cara Membuat Rebusan Jitu Dari Mahkota Dewa untuk Asam Urat, http://www. Asam urattiens.com, diakses 10 mei 2017.

5. Ika dkk, 2017, Pengaruh Pemberian Rebusan Mahkota Dewa terhadap Kadar Asam Urat Darah pada Wanita Menopause, malang, junal kesehatan, Vol. 5 No. 1.

6. Kus Haryono, 2014, Korelasi Kadar Asam Urat Dalam Darah Dan Kristal Asam Urat dalam Urin, Makassar. Vol 6.No. 1.

7. La Ode Sarif, 2012, Asuhan keperawatan Gorontik, Nuha madika, Yokyakarta.

8. Mulyani, 2013, Menopause, cetakan yang pertama, Nuna Madika, Yokyakarta.

9. Notoatmodjo, 2012, Metode Penelitian Kesehatan, Rineka Cipta, Jakarta.

10. Riwidikdo, H, 2008, Statistika Kesehatan, Mitra Cendekia, Yogyakarta

11. Rohyami, 2008, Penentuzan Kandungan Flavonoid dari Ekstrak Metanol Daging Buah Mahkota Dewa (Phaleria macrocarpa Scheff Boerl), Yogyakarta, Vol. 5 No. 1.

12. Setiono, 2014, Analisis kebiasaan Makanan yang Menyebabkan Peningkatan Kadar Asam Urat, tasikmalaya, jurnal kesehatan kemunitas Indonesia, Vol. 10 No. 2.

13. Sholihah, 2014, Diagnosis And Gout Arthritis, lampung, Vol. 3 No. 7.

14. Suriana, 2014, Herbal sakti atasi asam urat, Mutiara allamah utama, Sukma Jaya.

15. Syukri, 2007, Asam urat dan Hiperuresemia, Banda Aceh, Majalah Kedokteran, Vol 40. No. 1.

16. Widyanto, 2014, Artritis Gout dan Perkembanganny, Rumah Sakit Aminah Blitar.Vol.10 No. 2.

17. Untari Ida, 2017, Hubungan Antara Pola Makan Dengan Penyakit Gout, STIKES PKU Muhammadiyah Surakarta. 